\title{
Amber inclusions from New Zealand
}

\section{Schmidt, Alexander}

2018-04

Schmidt , A, Kaulfuss , U , Bannister , J Baronov , V , Beimforde , C , Bleile, N , Borkent , A , Busch , A, Conran , J , Engel , M , Harvey , M , Kennedy , E , Kerr , P , Kettunen , E J , Kiecksee , A , Lengeling , F , Lindqvist , J , Maraun , M , Mildenhall , D , Perrichot , V , Rikkinen , J , Sadowski , E-M , Seyfullah , L , Stebner , F , Szwedo , J , Ulbrich , P \& Lee , D 2018 , ' Amber inclusions from New Zealand ', Gondwana Research , vol. 56 , pp. 135-146 . https://doi.org/10.1016/

http://hdl.handle.net/10138/310825

https://doi.org/10.1016/j.gr.2017.12.003

cc_by_nc_nd

acceptedVersion

Downloaded from Helda, University of Helsinki institutional repository.

This is an electronic reprint of the original article.

This reprint may differ from the original in pagination and typographic detail.

Please cite the original version. 


\section{Amber inclusions from New Zealand}

Alexander R. Schmidt ${ }^{a,}{ }^{,}$, Uwe Kaulfuss ${ }^{b}$, Jennifer M. Bannister ${ }^{c}$, Viktor Baranov ${ }^{d}$, Christina

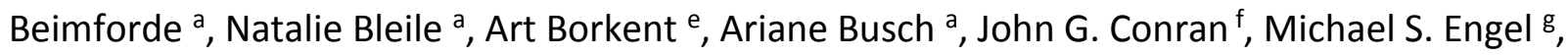
MarkHarvey h, Elizabeth M. Kennedy ${ }^{\text {, }}$ Peter H. Kerr ${ }^{j}$, Elina Kettunen ${ }^{\text {, }}$, Anna Philie Kiecksee a , Franziska Lengeling ${ }^{a}$, Jon K. Lindqvist ${ }^{b}$, MarkMaraun ', Dallas C. Mildenhall ${ }^{\text {, }}$, Vincent Perrichot ${ }^{m}$, Jouko Rikkinen k,n, Eva-Maria Sadowski a, Leyla J. Seyfullah a , Frauke Stebner o,p, Jacek Szwedo q, Philipp Ulbrich ${ }^{a}$, Daphne E. Lee ${ }^{b, *}$

a Department of Geobiology, University of Göttingen, 37077 Göttingen, Germany

b Department of Geology, University of Otago, Dunedin 9054, New Zealand

c Department of Botany, University of Otago, Dunedin 9054, New Zealand

d Department of River Ecology and Conservation, Senckenberg Research Institute and Natural History Museum Frankfurt, 63571 Gelnhausen, Germany

e Research Associate of the Royal British Columbia Museum and the American Museum of Natural History, 691-8th Ave. SE, Salmon Arm, British Columbia, V1E 2C2, Canada

f ACEBB \& SGC, School of Biological Sciences, DX 650 312, The University of Adelaide, SA 5005, Australia g Department of Entomology, Natural History Museum, and Department of Ecology \& Evolutionary Biology, University of Kansas, Lawrence, Kansas 66045, USA

h Western Australian Museum, Welshpool, WA 6986, Australia

i GNS Science, Lower Hutt 5040, New Zealand

j California Department of Food and Agriculture, Sacramento, CA 95832, USA

k Department of Biosciences, 00014 University of Helsinki, Finland

I J.F. Blumenbach Institute of Zoology and Anthropology, University of Göttingen, 37073 Göttingen,

Germany

m Univ Rennes, CNRS, Géosciences Rennes - UMR 6118, 35000 Rennes, France

n Finnish Museum of Natural History, 00014 University of Helsinki, Finland

o Steinmann Institute, University of Bonn, 53115 Bonn, Germany

p Department of Entomology, State Museum of Natural History Stuttgart, 70191 Stuttgart, Germany

q Department of Invertebrate Zoology and Parasitology, University of Gdańsk, 80-309 Gdańsk, Poland 


\begin{abstract}
Terrestrial ecosystems of the long-isolated former Gondwanan landmass of New Zealand are hotspots of modern global biodiversity, based on the level of endemism and distinctiveness of the biota. However, little is known of the evolutionary history of the rarely preserved but diverse, distinctive, fragile, mainly soft-bodied organisms such as arthropods and fungi that comprise $95 \%$ of biodiversity in forest ecosystems. Our discovery of fossils preserved in Oligocene/Miocene amber of araucarian origin reveals a diverse invertebrate and fungal biota and complex ecological networks. These fossils comprise 10 orders and approximately 20 families of terrestrial arthropods and include representatives of Pseudoscorpiones, Acari, Araneae, Collembola, Hemiptera, Psocoptera, Hymenoptera, Coleoptera, Lepidoptera and Diptera, together with nematodes, mold fungi and araucarian wood. Ecologically the fossils encompass predators such as spiders with web remains, soil and bark mites, detritivores, parasites, fungivores and decomposers, fungi that grew on solidified resin flows, as well as predatory fungi. This study reports the first major amber deposit with an abundance of biological inclusions from the Southern Hemisphere and the only Cenozoic one of verified araucarian origin. These fossils expand the global record and evolutionary history of many arthropod and fungal groups, providing insights into mid-Cenozoic araucarian forest ecosystems and resolving controversial issues around the antecedents of the modern New Zealand terrestrial biota.
\end{abstract}

Keywords: Amber, Arachnida, Fungi, Hexapoda, Southern Hemisphere 


\section{Introduction}

Amber is produced by several conifers (e.g. Araucariaceae, Cupressaceae) and some angiosperms (e.g. Dipterocarpaceae, Fabaceae). Because of its three-dimensional matrix and its chemical properties, amber uniquely preserves fragile, soft-bodied organisms that comprise much of the biodiversity in forest ecosystems. Of the hundreds of mainly Northern Hemisphere amber deposits (Martínez-Delclòs et al., 2004), only a dozen or so (e.g., Baltic, Burmese, Dominican ambers) contain abundant biological inclusions (Penney, 2010). Similarly, amber from the former Gondwanan landmasses contains few biological inclusions (Schmidt et al., 2010) and none to date is of verified araucarian origin.

Terrestrial ecosystems of the long-isolated landmass of New Zealand are notable modern global biodiversity hotspots (Myers et al., 2000), based on the level of endemism and distinctiveness of the biota. However, because of the rarity of fossils of all but higher plants, the history of the terrestrial biota is complex and controversial, with ongoing debates about its origin, antiquity and evolutionary history (e.g., Goldberg et al., 2008; Landis et al., 2008; Giribet and Boyer, 2010; Macfarlane et al., 2010; Buckley et al., 2015; Gibbs, 2016). The typically small, mainly soft-bodied organisms such as fungi and invertebrates preserved in amber have potential to contribute to this debate and to enhance our understanding of the role of evolution, extinction and environmental change in the formation of New Zealand's forest ecosystems. In particular, fossil insects preserved in amber can add greatly to knowledge of the antecedents of the New Zealand insect fauna which "is an important part of the global fauna, in age, diversity and uniqueness" (Buckley et al., 2015: 19).

New Zealand hosts one of the largest accumulations of subfossil resin (copal) on Earth, with about 500,000 tonnes of 'kauri gum' derived from living and subfossil Agathis australis (D.Don) Lindl. (Araucariaceae) exported since 1860 (Hayward, 1989). Similarly, extensive deposits of fossil resin (amber) of Cretaceous and Cenozoic age occur as droplets, layers and blocks in lignite (low grade brown coal), sandstones and mudstones throughout New Zealand (Fig. 1A-D). Commonly bubblefilled and opaque (Fig. 1C, D), the amber was thought to be devoid of fossils. However, thorough screening of several thousand New Zealand amber samples, combined with new preparation techniques, has revealed numerous three-dimensionally-preserved organisms and considerable biological and ecological complexity.

Here, we report on the first fossiliferous ambers from New Zealand. The late Oligocene and early Miocene fossils include a diverse range of arthropods and fungi. Most are new species and 
some represent the first global fossil records at genus and subfamily level. Together with pollen, leaves and wood from the same sites, the fossils enable us to reconstruct ecosystems in ancient Southern Hemisphere araucarian forests for the first time.

\section{Materials and methods}

Amber samples have been collected from over 30 sites throughout New Zealand and four localities have yielded identifiable inclusions, so far.

\subsection{Geology and age of the fossiliferous amber localities}

The fossiliferous amber pieces were collected in the Otago and Southland regions of the South Island of New Zealand (Fig. 1A). Most of the inclusions occurred in amber pieces found at Harliwich's Pit, an opencast mine in the East Roxburgh coalfield, Central Otago (Fig. 1B), which exposes a 45-m-thick lignite seam beneath quartz sand. The amber-bearing strata are part of the Dunstan Formation, which together with the overlying Bannockburn Formation forms the Manuherikia Group (Mildenhall, 1989). Along with lignite, the Dunstan Formation comprises alluvial conglomerate, sandstone and mudstone (Douglas, 1986). Based on palynological fossils such as Acaciapollenites myriosporites (Cookson) Mildenh. and Haloragacidites haloragoides Cookson \& K.M. Pike and other spores and pollen of the Spinitricolpites latispinosus (D.J. Mclntyre) Mildenh. \& Pocknall Zone, the age of the East Roxburgh coalfield is estimated to be Burdigalian (early Miocene, 19-16 Ma) (Mildenhall and Pocknall, 1989). Other inclusions have been extracted from amber in a lignite deposit in the Pomahaka Formation, west Otago, a late Oligocene estuarine deposit with many thin lignite seams interspersed with mudstones and siltstones (Lindqvist et al., 2016). A single oribatid mite came from a lignite of the East Southland coalfield on Cosy Dell farm, Southland and a few specimens from a thin lignite exposed in the base of a clay pit at Hyde, Otago. The latter sites are early Miocene in age (Mildenhall and Pocknall, 1989; Isaac and Lindqvist, 1990).

The age of the amber of each locality corresponds to that of the host lignites. The amber is either preserved in situ in the lignites, or has undergone only minor redeposition following 
localized water transport within the swamp forest deposits. Some amber specimens are associated closely with wood and a few with rooted trees and there is no evidence to support redeposition of the amber at these four inclusion-bearing sites.

\subsection{Preparation and microscopy}

Most New Zealand amber is opaque and bubble-filled or only semitranslucent and quite brittle. After initial inspection, samples were divided along fissures or borders between successive resin flows using a dissecting needle. For investigation, the resulting amber fragments were ground and polished manually using a series ofwet silicon carbide papers [grit fromFEPA P 600-4000, Struers] to produce smooth surfaces for investigation. Millimetre after millimetre of amber surface was removed successively from each amber piece, with frequent checks under a dissection microscope to check if inclusions appeared in the semi-translucent amber. If inclusions were detected, the fragile amber specimens were embedded in a high-grade epoxy under vacuum [see Nascimbene and Silverstein, 2000 for protocols]. As the epoxy enters cracks and cavities, it improves amber stability and the optical qualities by preventing refractive distortions and mirrored reflections and by making the amber more translucent. In detail, the specimens were initially attached to silicone ice cube trays using Epoxy-Minute Adhesive (Weicon) with inclusions orientated horizontally in the upper part of the amber pieces. After hardening, a two-component epoxy resin with optical features similar to the amber (EPO-TEK 301-2, Epoxy Technology) was used for embedding the amber specimens in a ratio of 100 [resin]:37 [hardener], with the ice cube compartments filled with epoxy resin in a fume hood. To remove emerging air bubbles and to ensure that the epoxy fills all microfissures, the preparations were placed in a vacuum chamber (VO-200, Memmert) at 50 millibar for one hour. This treatment stabilizes the amber and clears it, allowing a better view of the enclosed organisms.

The embedded samples were left for five days to harden, removed from the silicone forms and further manually polished using a Buehler EcoMet 250 polishing machine and CarbiMet (Buehler) silicon carbide papers. Prepared amber specimens were mounted on a glass microscopic slide with the upper polished surface oriented horizontally. A drop of water was applied to the upper surface of the amber and covered with a glass coverslip to reduce light scattering from fine surface scratches and improve optical resolution. 
The amber inclusionswere studied under a Carl Zeiss Stereo Discovery V8 dissection microscope and under a Carl Zeiss AxioScope A1 compound microscope, equipped with Canon 5D digital cameras. In most instances, incident and transmitted light were used simultaneously. The light-microscopic images are digitally stacked photomicrographic composites of up to 120 individual focal planes obtained using the software package Helicon Focus 6.2.2 for an enhanced illustration of the three-dimensional inclusions.

\subsection{Repository}

The fossiliferous amber pieces (see Table 1) are deposited in the collections of the Geology Museum, University of Otago, Dunedin, New Zealand and catalogued with OU numbers.

\section{Results and discussion}

\subsection{Source trees and plant remains}

The amber was derived from araucarian source trees which have a fossil record from the Late Cretaceous through to the present day in New Zealand based on pollen, foliage and wood fossils (Lindqvist, 1986; Lee et al., 2007, 2012, 2016a). It is most likely to have been produced by one or more extinct species of Agathis Salisb. (Evans, 1937; Lambert et al., 1993; Seyfullah et al., 2015). There is fossil evidence for other now locally extinct araucarian genera (Von Ettingshausen, 1891; Raine et al., 2011): Araucaria Juss. (now living in eastern Australia, New Guinea, New Caledonia, Norfolk Island and South America) and Wollemia W.G. Jones, K.D. Hill \& J.M. Allen (discovered still living in Australia in 1994). However, FTIR spectra from Idaburn amber samples suggest an Agathis origin (Seyfullah et al., 2015).

In New Zealand, as in most fossiliferous ambers, macrofossil plant remains are rare because larger plant fragments that get trapped tend to stick to the resin surfacewhere they degrade rapidly. Small fragments of araucarian wood are preserved (Fig. 1E), as are some plant scales and stellate plant hairs (Fig. 20). Araucarian wood and leaves with cuticular preservation are also preserved at some New Zealand sites with plentiful amber (Lee et al., 2007; Ferguson et al., 2010). 


\subsection{Arthropods}

Arthropods are the most diverse fossils in New Zealand amber with over 80 individual specimens in at least 10 orders and approximately 20 families. These fossils represent an impressive diversity, including the arachnid orders Acari, Araneae and Pseudoscorpiones and at least 14 families of Hexapoda in the orders Collembola, Hemiptera, Psocoptera, Hymenoptera, Coleoptera, Lepidoptera, and Diptera (Table 1).

\subsubsection{Pseudoscorpiones}

A notable discovery is two pseudoscorpions, one ofwhich belongs to Philomaoria Chamberlin (Fig. $2 \mathrm{~A})$, the sole genus of Cheliferidae subfamily Philomaoriinae. The modern New Zealand pseudoscorpion fauna of 67 species is highly endemic (94\%) (Harvey, 2011; Sirvid et al., 2011) and Philomaoria today occurs only in the southwest Pacific (New Zealand, Lord Howe Island and New Caledonia) (Harvey, 1996). The Philomaoria specimen is the first fossil representative globally of this subfamily and the two reported here are only the second and third fossil pseudoscorpions from the Southern Hemisphere. The first was a specimen from Australian Cape York amber which; however, derives from south-east Asia (Sonibare et al., 2014). The New Zealand fossil pseudoscorpions differ markedly from those recovered from Baltic, Mexican, Dominican and Lebanese ambers (Penney, 2010). Their ecology is poorly known, but they are widespread predators of small arthropods, living under rocks, in soil, leaf litter and on trees beneath bark, or associated with moss, lichens and other epiphytes; many species also cohabit with social insects and ground dwelling animals and birds (Minor and Robertson, 2006).

\subsubsection{Acari}

Other significant inclusions comprise a variety of mites (Fig. 2B-K) that represent adult and juvenile developmental stages of representatives of the Mesostigmata, Oribatida, Astigmata and Prostigmata. They provide an impressive sample of diverse soil-dwelling mites typical of modern 
warm temperate to subtropical forest floors. The presence of the oribatid family Oribotritiidae (Euphthiracaroidea), the endophagous larvae of which preferentially live in deadwood or decaying coniferous and deciduous leaf litter, is supported by the presence of conifer foliage, pollen and wood at the Roxburgh site.

\subsubsection{Araneae}

Other arachnids include several well-preserved, though undeterminable juvenile spiders (Fig. 2L, M). The spiders appear to represent web-builders, rather than free-living hunters. Well-preserved spider web filaments also occur with trapped insect remains, fecal pellets, fungi and stellate plant hairs (Fig. 2N, O).

\subsubsection{Collembola}

Springtails (Fig. 2P) include new species of Entomobryidae, one of the most species-rich families among Collembola (Bellinger et al., 1996-2017; Sánchez-García and Engel, 2016). These fossils resemble the extant genus Entomobrya Rondani and represent the first springtail fossils from New Zealand and Australia.

\subsubsection{Hemiptera}

Hemiptera are represented by a planthopper nymph and four inclusions of sternorrhynchans, or scale insects. The nymph (Fulgoromorpha) seems to represent a 3rd instar (Fig. 3A) from one of so-called 'higher Fulgoroidea' families, bearing some affinities to nymphs of Tropiduchidae which are currently present in Australia and New Caledonia, but absent from New Zealand (Macfarlane et al., 2010). Inclusions of sternorrhynchans (Fig. 3B, C) may represent males, but family assignment is not possible. Scale insects of 10 families are reported from New Zealand (Macfarlane et al., 2010), with felted scales (Eriococcidae), mealybugs (Pseudococcidae) and armoured scales (Diaspididae) being the most speciose in the extant fauna and with the highest 
number of endemic species. Representatives of these families are known to feed on Araucariaceae, supporting identification of the resin source. Fossils of in situ Diaspididae are also present on Elaeocarpaceae leaves recovered from the Miocene-aged Foulden Maar diatomite deposit (Harris et al., 2007).

\subsubsection{Psocoptera}

A single specimen of Psocoptera recovered from Roxburgh amber is the first fossil record of the order from New Zealand (Fig. 3D). It is preserved in mildly turbid amber, best visible in dorsal view. The specimen is quite setose, and the antennae have numerous elongate, erect setae, with the antennomeres annulated. The margins of the wings and veins have a single row of setae except for the posterior cubital vein which lacks setae altogether, and there are no crossveins present. The specimen is generally reminiscent of the genus Zelandopsocus Tillyard (Pseudocaeciliidae), a genus endemic to New Zealand today. This family of largely leaf-associated psocopterans (Mockford, 1984) has a scarce fossil record, with only one species described from Baltic amber (Roesler, 1940) and one record from Miocene Mexican amber (Poinar, 1992). The modern New Zealand psocopteran fauna, although relatively diverse, is largely a subset of Australian groups (Smithers, 1969; Thornton, 1985).

\subsubsection{Hymenoptera}

A single worker ant (Formicidae, Fig. 3E) was found in a piece of dusty amber. Presence of a scalelike petiole and absence of postpetiole and sting or acidopore indicate the subfamily Dolichoderinae. Key features for a genus-level determination are obscured and will require further investigation using micro-tomographic techniques. New Zealand's extant endemic ant fauna is surprisingly small, with only 11 species in six genera (Don, 2007) but many recent introductions from Australia and the Pacific have become established, including 10 species of Dolichoderinae (AntWeb, 2017). New Zealand's ant fossil record is also meagre, with only four species in three genera described from compression fossils from the early Miocene Foulden Maar (Kaulfuss et al., 2014a; Kaulfuss and Dlussky, 2015). Among these, an isolated wing was tentatively assigned to 
Dolichoderinae. The worker specimen from Roxburgh amber is thus the first definitive fossil dolichoderine from New Zealand, establishing the subfamily in the region in the Miocene. The timing of extinction of the native dolichoderines cannot be assessed, but the amber fossil supports previous assumptions that the endemic New Zealand ant fauna was more diverse in the past, at least during the Miocene (Don, 2007; Kaulfuss et al., 2014a, 2014b; Kaulfuss and Dlussky, 2015).

Partial remains of three parasitic wasps are also present. Details of the wing venation and head structures are missing or largely obscured, but two specimens are assignable to the family Scelionidae, subfamily Telenominae (Fig. 3F), and probably to the widespread genus Trissolcus Ashmead which are well-known parasitoids of hemipteran eggs. The glabrous compound eyes, broad and concolorous abdominal segments, slender basal antennal segment, sculptured frons, and sparse, subdecumbent setae are suggestive of Trissolcus among telenomines. The third wasp (Fig. 3G) exhibits a distinctive marginal fringe of setae on the preserved part of wings, and the mid and hind legs have five segmented tarsomeres. The latter would indicate a potential placement among some of the putatively primitive lineages of Mymaridae, although in the absence of information regarding the apical antennomeres, this is impossible to confirm. Both Scelionidae and Mymaridae are common fossils in amber, but this is their first fossil record from New Zealand, where there are diverse extant, endemic species with various host taxa (Valentine andWalker, 1991).

\subsubsection{Coleoptera}

An amber-preserved beetle and partial specimens have been recovered. One is apparently a phytophagan of the family Chrysomelidae, with the metatarsus tetramerous and metatarsomere III deeply bilobed (Fig. 3H). The only other identifiable beetle remains include larval hairs (Fig. 3I) of the family Dermestidae (carpet beetles), whose larvae are usually scavengers of dry, dead animals whereas the adults are mostly nectar or pollen feeders (Lawrence and Britton, 1991). Beetles have a long albeit sparse fossil record in New Zealand, with unidentified isolated elytra reported from the Triassic and Late Cretaceous (Kaulfuss et al., 2014b), as well as a midCretaceous member of the Carabidae: Boscini (Stilwell et al., 2016). There are also abundant beetles from a range of families in the Miocene Foulden Maar and Hindon Maar deposits (Kaulfuss 
et al., 2014b; Lee et al., 2016b). The new amber fossils expand the range of families and fossil ecological niches occupied by New Zealand Coleoptera.

\subsubsection{Lepidoptera}

Evidence for these is confirmed by the presence of microscopic wing scales (Fig. $3 \mathrm{~J}$ and K), but these do not allow for a familial determination. These are, however, only the third report of fossil lepidopterans from New Zealand, the previous likewise being isolated scales from the Late Cretaceous and Eocene (Evans, 1931; Harris and Raine, 2002).

\subsubsection{Diptera}

Fossil Diptera are poorly known from New Zealand, with only a larval Bibionidae from the Eocene (Harris, 1983) and several adult Tipulidae and possible Muscidae from the Oligo-Miocene of South Island (Kaulfuss et al., 2014b). Four amber inclusions of male Chironomidae represent the subfamily Orthocladiinae and belong to, or are closely related to the genus Bryophaenocladius Thienemann, (Fig. 3L). Two fossil species are known from Eocene Baltic and Rovno amber (Baranov et al., 2015). There are no published reports of living representatives of the genus from New Zealand, although the barcoding database BOLD reported DNA of $B$. ictericus from New Zealand which might represent an erroneous record, or may indicate a recent introduction of this Northern Hemisphere species. Many modern representatives of the genus have either terrestrial or madicolous larvae, living in the wet soil, vegetation or thin films of water (Armitage et al., 1995).

A gallmidge (Cecidomyiidae, Fig. 3M), recognized by its habitus and wing venation represents the second fossil example from Australasia, the previous report coming from Australian Cape York amber (Hand et al., 2010). The oldest known fossil is from the Cretaceous/Jurassic of Siberia (Kovalev, 1990) and Cecidomyiidae are abundant in Northern Hemisphere amber from the Cretaceous to the Miocene (e.g. Arillo and Nel, 2000; Solórzano Kraemer, 2007; Ross, 2010). Most fossil species are from Eocene Baltic and Rovno ambers, although gall midges are also very common in Eocene Cambay amber (F. Stebner, unpubl. obs.) and are also the most frequent dipteran inclusions in Miocene Mexican amber (Solórzano Kraemer, 2007). 
One of the most significant inclusions in New Zealand amber is the fungus gnat Neoaphelomera Miller (Mycetophilidae; Fig. 3N) which represents the first fossil known for the genus globally. Neoaphelomera comprises 13 extant species distributed in New Zealand, Australia, Chile, New Caledonia and Brazil (Bechev, 2000). New Zealand has a diverse and unusual extant regional mycetophilid fauna (Davies, 1988); however, only one austral compression fossil of the Mycetophilidae is known from the Cenozoic Redbank Plains Series in Queensland, Australia (Riek, 1954).

Two female biting midges (Ceratopogonidae) are present in Roxburgh amber. Specimen OU 33160.72 (Fig. 30) is likely a Forcipomyia Meigen but details of the wings, most features of the legs, and terminalia (i.e. genital and post genital abdominal segments) are obscured. The antennal flagellomeres (i.e. units of the third antennal segment) are equal, of more or less uniform length. Specimen OU 33160.64 (Fig. 3P) is a Dasyhelea Kieffer, also with details of the wings and terminalia in too poor condition to interpret. A single spermatheca was evident. A third specimen from Pomahaka is most likely Austrohelea Wirth \& Grogan and represents the first fossil record of this taxon. All three genera are present in the extant fauna of New Zealand, where there are nine species of Forcipomyia, three of Dasyhelea and four of Austrohelea (Debenham, 1989; Borkent, 2016). However, it is very likely that this extant fauna is poorly known and more species await discovery. The larvae of Forcipomyia are found in semiaquatic to terrestrial, moist microhabitats (e.g. under bark, in mosses), while those of Dasyhelea are aquatic and restricted to rock pools, pond edges and phytotelmata. Ceratopogonidae have one of the best-known fossil records of any insect family, with thousands of specimens representing 283 species in over 15 major amber deposits, ranging from early Miocene Dominican amber to Early Cretaceous Lebanese amber (Borkent, 2016). There is excellent congruence between the fossil record and cladistic relationships, with successively older fossils representing successively older lineages (Borkent, 2000). The discovery of Forcipomyia, Dasyhelea and Austrohelea in Miocene amber from New Zealand accords with known temporal and geographic patterns: Forcipomyia is otherwise known as far back as the early Eocene, in Cambay, Indian amber and the oldest record of Dasyhelea is from Eocene Baltic amber (Borkent, 2000; Stebner et al., 2017). Borkent (1991) showed that volcanic islands have a reduced fauna of Ceratopogonidae that includes only species from the following genera: Forcipomyia, Atrichopogon, Dasyhelea and Culicoides. Many members of these genera are easily dispersed. Continental islands have a far more diverse fauna, indicating their previous connections to mainland faunas. New Zealand has six additional genera, indicating its 
continental connections. The presence of Austrohelea in New Zealand amber further supports the hypothesis that at least part of New Zealand has always been emergent.

\subsection{Nematodes}

Several nematodes have been collected, including a specimen trapped by a predatory fungus (Fig. 4A). No fossil terrestrial nematodes have been reported previously from the Southern Hemisphere, although their fossil record reaches back to the early Devonian (Poinar et al., 2008).

\subsection{Fungi}

Most New Zealand amber fungal inclusions are hyphomycetes, i.e., mold-like, anamorphic stages of various filamentous fungi, especially Ascomycota. Extant hyphomycetes are a highly diverse group of considerable ecological importance and recently described fossil late Eocene epiphyllous fungi from New Zealand indicated a humid mesothermal paleoclimate at the time (Bannister et al., 2016; Conran et al., 2016). Many hyphomycetes are decomposers of organic matter, but parasites and pathogens of plants and animals are also common (Seifert et al., 2011).

Roxburgh amber preserves the only sootymold fossils known so far fromthe Southern Hemisphere. The tapering sooty mold hyphae found inside the New Zealand amber specimens belong to the family Metacapnodiaceae (Fig. 4B), with one hypha bearing the distinctive Capnophialophora S. Hughes conidial state (Fig. 4C). Sooty molds obtain their nutrition mainly from honeydew excreted by sap-sucking aphids and scale insects. They often form dense mats of dark mycelia covering various plant surfaces, sometimes interfering with photosynthesis (Perez et al., 2009). Sooty molds are today especially abundant in the Southern Hemisphere and extant taxa have been studied extensively in New Zealand (Hughes, 1976). Fossil sooty molds have been described previously from Northern Hemisphere ambers. They mostly include distinctive vegetative hyphae of the sooty mold family Metacapnodiaceae, with oldest representatives dating back to the Cretaceous (Rikkinen et al., 2003; Schmidt et al., 2014). The abundance and diversity of extant sooty molds in New Zealand, combined with the fossil findings from Roxburgh amber, suggests a long evolutionary history of these fungi in the region. 
Many New Zealand amber pieces contain hyphae and conidial chains of a dematiaceous hyphomycete (Fig. 4D, E) that predominantly grew on outer surfaces of solidified resin flows. They are observed accumulated on successive resin flows preserved inside amber pieces. These represent the most abundant fungal morphology in New Zealand amber and its conidia are found frequently in fecal pellets of mites trapped in the amber (Fig. 4F), demonstrating fungivory in Miocene New Zealand microarthropods. Morphologically similar microfungi have been described previously from European Oligocene and Eocene amber as Casparyotorula Rikkinen, A.R. Schmidt \& Kettunen (Kettunen et al., 2015), but the New Zealand hyphomycete is distinct from European species, based on its conidiogenesis and growth habit.

\section{Conclusions}

Study of the biota captured as inclusions in amber has greatly expanded our understanding of the evolution of terrestrial life in the Cretaceous and Cenozoic (Penney, 2010), but nearly all previous investigations are derived fromsamples in Northern Hemisphere forest ecosystems in Europe, Asia, and North and Central America. Exceptions fromthe Southern Hemisphere come from the Miocene of Peru and the Early Cretaceous of Congo, both ambers that are moderately fossiliferous but with limited or no paleobiological data published to date (Antoine et al., 2006; Petrulevičius et al., 2011; Perrichot et al., 2014, 2016). A recently described amber biota from Cape York, northern Australia of uncertain age is apparently allochthonous, deriving originally from dipterocarp forests in New Guinea or Southeast Asia (Sonibare et al., 2014). One block of the so-called Allendale amber from Victoria, Australia (Hills, 1957; Greenwood et al., 2000) has yielded a few arthropods including extant species of ants and beetles, suggesting it was a Pleistocene or younger copal rather than a 'Tertiary amber', of little significance for the study of ancient biota. Until now, the paucity of data from amber in the Southern Hemisphere has hindered our understanding of global terrestrial invertebrate and fungal evolution and ecology.

The New Zealand amber record is unusual globally in providing successive windows from the Cenozoic through to an extant ecosystem, from the same resin source, Araucariaceae. This is in marked contrast to most Northern Hemisphere amber deposits which reveal the biodiversity of long extinct tropical to temperate ecosystems that were fossilized over relatively short geological time frames (Penney, 2010). 
The fossil fungi were part of a diverse epiphytic community that grew on the resin-producing trees and some examples are morphologically similar to species growing on plant surfaces in the modern New Zealand. The epiphytic fungi in the Miocene of New Zealand indicate a year-round high humidity in these ancient forests.

The diverse invertebrate fossils in New Zealand amber include predators such as spiders (including web remains with prey), tiny carnivores such as pseudoscorpions, diverse soil-dwelling mites, detritivores such as springtails, biting and gall midges, fungus gnats and chironomids, parasitoid wasps, ants, carpet and leaf beetles, bark lice and lepidopteran wing scales. Nematodes (soft-bodied soil and litter micrometazoans) are also preserved, sometimes trapped by predatory fungi. Among the new species, many represent the first global fossil records of their lineages and they provide evidence for considerable ecological complexity. The fossils permit investigation of ecological interactions and their antiquity, including diet (fungal spores in mite guts); predation (prey in spider webs); parasitism (parasitic wasps) and the role of fungi (as corticolous, resinicolous and even nematophagous fungi). To date, these inclusions are derived from only four fossiliferous amber localities, but there are dozens of other New Zealand Paleogene and Neogene amber outcrops that have the potential to provide a Southern Hemisphere equivalent to major Northern Hemisphere amber deposits and extend the range of large amber deposits to Gondwana and its associated faunas. This wealth of data provides a unique window into the impact of significant geological events in the biotic history of New Zealand. For example, the impact and extent of Oligocene land erosion and marine transgression on New Zealand's arthropod lineages is uncertain, particularly as these events relate to estimating the origins of those few endemic families and the diversifications observed among others (Buckley et al., 2015). The New Zealand amber outcrops give direct observation into the faunas existing during these transitional epochs and, with the fidelity of preservation offered by such inclusions, offer the potential to confidently phylogenetically place fossils within a reliable framework. This will ultimately provide robust calibrations for combined analyses of morphological and molecular data as well as paleoecological contexts for understanding the evolution of this remarkable biota. 


\section{Acknowledgments}

We thank numerous landowners who allowed us to collect amber samples from their land, especially Ken Harliwich (Roxburgh), Trevor Copland (Waimumu), and Andrew Morris (Pomahaka). We thank Cyrille D'Haese (Paris), David Penney (Manchester), Bill Lee (Dunedin) and Marie-Claude Larivière (Auckland) for helpful information. We are grateful to three anonymous reviewers for constructive suggestions. This research was funded in part by a Marsden Grant (UOO1416) from the Royal Society of New Zealand and an Australian Research Grant (DP130104314).

\section{References}

Antoine, P.-O., De Franceschi, D., Flynn, J.J., Nel, A., Baby, P., Benammi, M., Calderón, Y., Espurt, N., Goswami, A., Salas-Gismondi, R., 2006. Amber from western Amazonia reveals Neotropical diversity during the middle Miocene. Proceedings of the National Academy of Sciences of the United States of America 103, 13595-13600.

AntWeb, 2017. New Zealand. Retrieved 7 Feb 2017. https://www.antweb.org.

Arillo, A., Nel, A., 2000. Two new fossil cecidomyiids flies from the Lower Cretaceous amber of Alava (Spain) (Diptera, Cecidomyiidae). Bulletin de la Société entomologique de France 105, 285-288.

Armitage, P.D., Cranston, P.S., Pinder, L.C.V. (Eds.), 1995. The Chironomidae: Biology and Ecology of Non-biting Midges. Chapman and Hall, London, UK

Bannister, J.M., Conran, J.G., Lee, D.E., 2016. Life on the phylloplane: Eocene epiphyllous fungi from Pikopiko Fossil Forest, Southland, New Zealand. New Zealand Journal of Botany 54, 412-432.

Baranov, V., Andersen, T., Hagenlund, L.K., 2015. A new species of Bryophaenocladius Thienemann, 1934 (Diptera, Chironomidae, Orthocladiinae) from Baltic amber. Norwegian Journal of Entomology 62, 53-56.

Bechev, D., 2000. World distribution of the genera of fungus gnats (Diptera: Sciaroidea, excluding Sciaridae). Studia Dipterologica 7, 543-552.

Bellinger, P.F., Christiansen, K.A., Janssens, F., 1996-2017. Checklist of the Collembola of the world. Retrieved 5 Apr 2017. http://www.collembola.org. 
Borkent, A., 1991. The Ceratopogonidae (Diptera) of the Galápagos Islands, Ecuador with a discussion of their phylogenetic relationships and zoogeographic origins. Entomologica Scandinavica 22, 97-122.

Borkent, A., 2000. Biting midges (Ceratopogonidae: Diptera) from Lower Cretaceous Lebanese amber with a discussion of the diversity and patterns found in other ambers. In: Grimaldi, D. (Ed.), Studies on Fossils in Amber, with Particular Reference to the Cretaceous of New Jersey. Backhuys Publishers, Leiden, pp. 355-451.

Borkent, A., 2016. World species of biting midges (Diptera: Ceratopogonidae). Retrieved 14 Mar 2017. http://wwx.inhs.illinois.edu/files/4514/6410/0252/CeratopogonidaeCatalog. pdf.

Buckley, T.R., Krosch, M., Leschen, R.A.B., 2015. Evolution of New Zealand insects: summary and prospectus for future research. Australian Entomology 54, 1-27.

Conran, J.G., Bannister, J.M., Reichgelt, T., Lee, D.E., 2016. Epiphyllous fungi and leaf physiognomy suggest an ever-wet humid mesothermal (subtropical) climate in the late Eocene of southern New Zealand. Palaeogeography, Palaeoclimatology, Palaeoecology 452, 1-10.

Davies, T.H., 1988. List of Mycetophilidae and Sciaridae (Diptera) collected in Hawkes Bay. New Zealand Entomologist 11, 12-14.

Debenham, M.L., 1989. Family Ceratopogonidae. In: Evenhuis, N.L. (Ed.), Catalog of the Diptera of the Australasian and Oceanian Regions. Bishop Museum Special Publication 86. Bishop Museum Press and Leiden, E.J. Brill, Honolulu, pp. 226-251.

Don, W. (Ed.), 2007. Ants of New Zealand. Otago University Press, Dunedin, NZ.

Douglas, B.J. (Ed.), 1986. Lignite resources of Central Otago (New Zealand Energy Research and Development Committee Publication P104). NZERDC, Auckland.

Evans, W.P., 1931. Traces of a lepidopterous insect from the Middle Waikato Coal Measures. Transactions and Proceedings of the New Zealand Institute 62, 99-101.

Evans, W.P., 1937. Note on the flora which yielded the Tertiary lignites of Canterbury, Otago and Southland. New Zealand Journal of Science and Technology 19, 188-193.

Ferguson, D.K., Lee, D.E., Bannister, J.M., Zetter, R., Jordan, G.J., Vavra, N., Mildenhall, D.C., 2010. The taphonomy of a remarkable leaf bed assemblage from the late Oligocene-early Miocene Gore Lignite Measures, southern New Zealand. International Journal of Coal Geology 83, 173-181.

Gibbs, G.W. (Ed.), 2016. Ghosts of Gondwana, Revised Edition: The History of Life in New Zealand. Craig Potton Publishing, Nelson, NZ. 
Giribet, G., Boyer, S.L., 2010. 'Moa's Ark'or 'Goodbye Gondwana': is the origin of New Zealand's terrestrial invertebrate fauna ancient, recent, or both? Invertebrate Systematics 24, 1-8.

Goldberg, J., Trewick, S.A., Paterson, A.M., 2008. Evolution of New Zealand's terrestrial fauna: a review of molecular evidence. Philosophical Transactions of the Royal Society B 363, 33193334.

Greenwood, D.R., Vadala, A.J., Douglas, J.G., 2000. Victorian Paleogene and Neogene macrofloras: a conspectus. Proceedings of the Royal Society of Victoria 112, 65-92.

Hand, S., Archer, M., Bickel, D., Creaser, P., Dettmann,M., Godthelp, H., Jones, A., Norris, B., Wicks, D., 2010. Australian Cape York amber. In: Penney, D. (Ed.), Biodiversity of Fossils in Amber from the Major World Deposits. Siri Scientific Press, Manchester, UK, pp. 69-79.

Harris, A.C., 1983. An Eocene larval insect fossil (Diptera Bibionidae) from north Otago, New Zealand. Journal of the Royal Society of New Zealand 13, 93-105.

Harris, A.C., Raine, J.I., 2002. A sclerite from a late Cretaceous moth (Insecta: Lepidoptera) from Rakaia Gorge, Canterbury, New Zealand. Journal of the Royal Society of New Zealand 32, 457-462.

Harris, A.C., Bannister, J.M., Lee, D.E., 2007. Fossil scale insects (Hemiptera, Coccoidea, Diaspididae) in life position on an angiosperm leaf from an early Miocene lake deposit, Otago, New Zealand. Journal of the Royal Society of New Zealand 37, 1-13.

Harvey, M.S., 1996. The biogeography of Gondwanan pseudoscorpions (Arachnida). Revue Suisse de Zoologie, Hors Série 1, 255-264. Harvey, M.S., 2011. Pseudoscorpions of the World, version 2.0. Retrieved 13 Apr 2017. http://www.museum.wa.gov.au/catalogues /pseudoscorpions.

Hayward, B.W., 1989. Kauri Gum and the Gumdiggers: A Pictorial History of the Kauri Gum Industry in New Zealand (Pictures from the Past). Bush Press, Auckland, NZ.

Hills, E.S., 1957. Fossiliferous Tertiary resin from Allendale, Victoria. Proceedings of the Royal Society of Victoria $69,15-20$.

Hughes, S.J., 1976. Sooty moulds. Mycologia 68, 693-820.

Isaac,M.J., Lindqvist, J.K., 1990. Geology and lignite resources of the East Southland Group, New Zealand. New Zealand Geological Survey Bulletin 101, 1-202.

Kaulfuss, U., Dlussky, G.M., 2015. Early Miocene Formicidae (Amblyoponinae, Ectatomminae, ?Dolichoderinae, Formicinae, and Ponerinae) from the Foulden Maar fossil Lagerstätte, New Zealand, and their biogeographic relevance. Journal of Paleontology 89, 1043-1055. 
Kaulfuss, U., Harris, A.C., Conran, J.G., Lee, D.E., 2014a. An early Miocene ant (subfam. Ambyloponinae) from Foulden Maar: the first fossil Hymenoptera from New Zealand. Alcheringa 38, 568-574.

Kaulfuss, U., Lee, D.E., Barratt, B.I.P., Leschen, R.A.B., Larivière, M.-C., Dlussky, G.M., Henderson, I.M., Harris, A.C., 2014b. A diverse fossil terrestrial arthropod fauna from New Zealand: evidence from the early Miocene Foulden Maar fossil Lagerstätte. Lethaia 48, 299-308. Kettunen, E., Grabenhorst, H., Gröhn, C., Dörfelt, H., Sadowski, E.-M., Rikkinen, J., Schmidt, A.R., 2015. The enigmatic hyphomycete Torula sensu Caspary revisited. Review of Palaeobotany and Palynology 219, 183-193.

Kovalev, V., 1990. Diptera. In: Rasnitsyn, A.P. (Ed.), Late Mesozoic Insects of Eastern Transbaikalia. Nauka, Moscow, pp. 123-177.

Lambert, J.B., Johnson, S.C., Poinar Jr., G.O., Frye, J.S., 1993. Recent and fossil resins from New Zealand and Australia. Geoarchaeology 8, 141-155.

Landis, C.A., Campbell, H.J., Begg, J.G., Mildenhall, D.C., Paterson, A.M., Trewick, S.A., 2008. The Waipounamu Erosion Surface: questioning the antiquity of the New Zealand land surface and terrestrial fauna and flora. Geological Magazine 145, 173-197.

Lawrence, J.F., Britton, E.B., 1991. Coleoptera (Beetles). In: Naumann, I.D., Carne, P.B., Lawrence, J.F., Nielsen, E.S., Spradberry, J.P., Taylor, R.W., Whitten, M.J., Littlejohn, M.J. (Eds.), The Insects of Australia: A Textbook for Students and Research Workers, 2nd edition Melbourne University Press, Carlton South, pp. 543-683.

Lee, D.E., Bannister, J.M., Lindqvist, J.K., 2007. Late Oligocene-Early Miocene leaf macrofossils confirm a long history of Agathis in New Zealand. New Zealand Journal of Botany 45, 565578.

Lee, D.E., Conran, J.G., Lindqvist, J.K., Bannister, J.M., Mildenhall, D.C., 2012. New Zealand Eocene, Oligocene and Miocene macrofossil and pollen records and modern plant distributions in the Southern Hemisphere. Botanical Review 78, 235-260.

Lee, D.E., Lee, W.G., Jordan, G.J., Barreda, V.D., 2016a. The Cenozoic history of New Zealand temperate rainforests: comparisonswith southern Australia and South America. New Zealand Journal of Botany 54, 100-127.

Lee, D.E., Kaulfuss, U., Bannister, J.M., Conran, J.G., 2016b. Biodiversity and palaeoecology of Hindon and Foulden Maars: two early Miocene Konservat-Lagerstätten from New Zealand. In: Laurie, J.R., Kruse, P.D., Garcia-Bellido, D.C., Holmes, J.D. (Eds.), Geological Society of 
Australia Abstracts Number 117, Palaeo Down Under 2, Adelaide 11-15 Jul 2016. Geological Society of Australia Inc, Adelaide, p. 40 (Abstract volume).

Lindqvist, J.K., 1986. Teredinid-bored Araucariaceae logs preserved in shoreface sediments, Wangaloa Formation (Paleocene), Otago, New Zealand. New Zealand Journal of Geology and Geophysics 29, 253-261.

Lindqvist, J.K., Gard, H.J.L., Lee, D.E., 2016. Geological setting, sedimentology and biota of the estuarine late Oligocene Pomahaka Formation, New Zealand. New Zealand Journal of Geology and Geophysics 59, 352-365.

Macfarlane, R.P., Maddison, P.A., Andrew, I.G., Berry, J.A., Johns, P.M., Hoare, R.J.B., Larivière, M.C., Greenslade, P., Henderson, R.C., Smithers, C.N., et al., 2010. Phylum Arthropoda subphylum Hexapoda: Protura, springtails, Diplura, and insects. In: Gordon, D.P. (Ed.), New Zealand Inventory of Biodiversity. Kingdom Animalia. Chaetognatha, Ecdysozoa, Ichnofossils vol. 2. Canterbury University Press, Christchurch, pp. 233-467.

Martínez-Delclòs, X., Briggs, D.E.G., Peñalver, E., 2004. Taphonomy of insects in carbonates and amber. Palaeogeography, Palaeoclimatology, Palaeoecology 203, 19-64.

Mildenhall, D.C., 1989. Summary of the age and paleoecology of the MioceneManuherikia Group, Central Otago, New Zealand. Journal of the Royal Society of New Zealand 19, 19-29.

Mildenhall, D.C., Pocknall, D.T., 1989. Miocene-Pleistocene spores and pollen fromCentral Otago, South Island, New Zealand. New Zealand Geological Survey Paleontological Bulletin 59, 1128.

Minor, M.A., Robertson, A.W., 2006. Soil bugs - an illustrated guide to New Zealand soil invertebrates (updated 29 Apr 2015). Retrieved 13 Apr 2017. http://soilbugs.massey. ac.nz.

Mockford, E.L., 1984. Relationships among philotarsid and pseudocaeciliid genera and a proposed new family, Bryopsocidae (Psocoptera). Psyche 91, 309-318.

Myers, N.,Mittermeier, R.A., Mittermeier, C.G., Da Fonseca, G.A., Kent, J., 2000. Biodiversity hotspots for conservation priorities. Nature 403, 853-858. Nascimbene, P.C., Silverstein, H., 2000. The preparation of fragile Cretaceous ambers for conservation and study of organismal inclusions. In: Grimaldi, D. (Ed.), Studies on Fossils in Amber,with Particular Reference to the Cretaceous of New Jersey. Backhuys Publishers, Leiden, pp. 93-102. Penney, D. (Ed.), 2010. Biodiversity of Fossils in Amber from the Major World Deposits. Manchester, Siri Scientific Press. 
Perez, J.L., French, J.V., Summy, K.R., Baines, A.D., Little, C.R., 2009. Fungal phyllosphere communities are altered by indirect interactions among trophic level. Microbial Ecology 57, 766-777.

Perrichot, V., Antoine, P.-O., Salas-Gismondi, R., Flynn, J.J., Engel, M.S., 2014. The genus Macroteleia Westwood in Middle Miocene amber from Peru (Hymenoptera, Platygastridae s.I., Scelioninae). ZooKeys 426, 119-127.

Perrichot, V., Boudinot, B.E., Cole, J., Delhaye-Prat, V., Esnault, J., Goldman, Y., Nohra, Y.A., Schmidt, A.R., 2016. African fossiliferous amber: a review. In: Penney, D., Ross, A.J. (Eds.), 7th International Conference on Fossil Insects, Arthropods and Amber, Edinburgh, UK, Abstract Book, p. 41.

Petrulevičius, J.F., Nel, A., De Franceschi, D., Goillot, C., Antoine, P.-O., Salas-Gismondi, R., Flynn, J.J., 2011. First fossil blood sucking Psychodidae in South America: a sycoracine moth fly (Insecta: Diptera) in the middle Miocene Amazonian amber. Insect Systematics and Evolution $42,87-96$.

Poinar Jr., G.O., 1992. Life in Amber. Stanford University Press, Stanford, CA.

Poinar Jr., G.O., Hass, H., Kerp, H., 2008. Palaeonema phyticum gen. n., sp. n. (Nematoda: Palaeonematidae fam. n.), a Devonian nematode associated with early land plants. Nematology 10, 9-14.

Raine, J.I., Mildenhall, D.C., Kennedy, E.M., 2011. New Zealand fossil spores and pollen: an illustrated catalogue, 4th edition (GNS Science Miscellaneous Series No. 4). (updated 5 May 2013). Retrieved 13 Apr 2017. http://www.gns.cri.nz/what/earthhist/fossils/ spore_pollen/catalog/index.htm.

Riek, E.F., 1954. The fossil Diptera of the Tertiary Redbank Plains Series, Queensland. Proceedings of the Linnean Society of New South Wales 79, 58-60.

Rikkinen, J., Dörfelt, H., Schmidt, A.R., Wunderlich, J., 2003. Sooty moulds from European Tertiary amber, with notes on the systematic position of Rosaria ('Cyanobacteria'). Mycological Research 107, 251-256.

Roesler, R., 1940. Neue Copeognathen. Arbeiten über Morphologische und Taxonomische Entomologie aus Berlin-Dahlem 7, 236-244.

Ross, A., 2010. Amber, the Natural Time Capsule. 2nd ed. Natural History Museum, London. 
Sánchez-García, A., Engel, M.S., 2016. Springtails from the Early Cretaceous amber of Spain (Collembola: Entomobryomorpha), with an annotated checklist of fossil Collembola. American Museum Novitates 3862, 1-47.

Schmidt, A.R., Perrichot, V., Svojtka, M., Anderson, K.B., Belete, K.H., Bussert, R., Dörfelt, H., Jancke, S., Mohr, B., Mohrmann, E., et al., 2010. Cretaceous African life captured in amber. Proceedings of the National Academy of Sciences of the United States of America 107, 73297334.

Schmidt, A.R., Beimforde, C., Seyfullah, L.J.,Wege, S.-E., Dörfelt, H., Girard, V., Grabenhorst, H., Gube, M., Heinrichs, J., Nel, A., et al., 2014. Amber fossils of sooty moulds. Review of Palaeobotany and Palynology 200, 53-64.

Seifert, K., Morgan-Jones, G., Gams,W., Kendrick, B., 2011. The Genera of Hyphomycetes. Utrecht, CBS-KNAW Fungal Biodiversity Centre. Seyfullah, L.J., Sadowski, E.-M., Schmidt, A.R., 2015. Species-level determination of closely related araucarian resins using FTIR spectroscopy and its implications for the provenance of New Zealand amber. PeerJ 3, e1067.

Sirvid, P.J., Zhang, Z.-Q., Harvey, M.S., Rhode, B.E., Cook, D.R., Bartsch, I., Staples, D.A., 2011. Phylum Arthropoda Chelicerata: horseshoe crabs, arachnids, sea spiders. In: Gordon, D.P. (Ed.), New Zealand Inventory of Biodiversity. Kingdom Animalia. Chaetognatha, Ecdysozoa, Ichnofossils vol. 2. Canterbury University Press, Christchurch, pp. 50-89.

Smithers, C.N., 1969. The Psocoptera of New Zealand. Records of the Canterbury Museum 7, 259344. Solórzano Kraemer, M.M., 2007. Systematic, palaeoecology, and palaeobiogeography of the insect fauna from Mexican amber. Palaeontographica A 282, 1-133.

Sonibare, O.O., Agbaje, O.B., Jacob, D.E., Faithfull, J., Hoffmann, T., Foley, S.F., 2014. Terpenoid composition and origin of amber from the Cape York Peninsula, Australia. Australian Journal of Earth Sciences 61, 979-985.

Stebner, F., Szadziewski, R., Singh, H., Gunkel, S., Rust, J., 2017. Biting midges (Diptera: Ceratopogonidae) from Cambay amber indicate that the Eocene fauna of the Indian subcontinent was not isolated. PLoS ONE 12 (1), e0169144.

Stilwell, J.D., Vitacca, J.J., Mays, C., 2016. South polar greenhouse insects (Arthropoda: Insecta: Coleoptera) from the mid-Cretaceous Tupuangi Formation, Chatham Islands, eastern Zealandia. Alcheringa 40, 502-508.

Thornton, I.W.B., 1985. The geographical and ecological distribution of arboreal Psocoptera. Annual Review of Entomology 30, 175-196. 
Valentine, E.W., Walker, A.K., 1991. Annotated Catalogue of New Zealand Hymenoptera, Department of Scientific and Industrial Research, Plant Protection Report No. 4. Auckland.

Von Ettingshausen, C., 1891. A description of species of the Tertiary flora of New Zealand.

Transactions and Proceedings of the New Zealand Institute 23, 250-310. 


\section{TABLES}

Table 1. New Zealand amber inclusions from the early Miocene of Roxburgh, Hyde, and Cosy Dell, and from the late Oligocene of Pomahaka, South Island, with collection numbers of the Geology Museum, University of Otago, Dunedin.

\begin{tabular}{|c|c|c|c|c|}
\hline Classification & Affiliation & Provenance & Specimen & Figure \\
\hline Arachnida & Acari, Astigmata & Roxburgh & OU 33160.14 & $2 \mathrm{~J}$ \\
\hline Arachnida & Acari, Astigmata & Roxburgh & OU 33160.36 & \\
\hline Arachnida & \multicolumn{2}{|c|}{ Acari, Mesostigmata, Gamasina Roxburgh } & OU 33160.20 & $2 \mathrm{~K}$ \\
\hline Arachnida & \multicolumn{2}{|c|}{ Acari, Oribatida, Scheloribatidae Roxburgh } & OU 33160.19 & $2 \mathrm{D}$ \\
\hline Arachnida & \multicolumn{2}{|c|}{ Acari, Oribatida, Scheloribatidae (Liebstadia) Roxburgh } & OU 33160.21 & $2 \mathrm{E}$ \\
\hline Arachnida & Acari, Oribatida & Roxburgh & OU 33160.86 & \\
\hline Arachnida & \multicolumn{3}{|c|}{ Acari, Oribatida, Euphthiracaroidea, Oribotritiidae Cosy Dell OU 33161.1} & $2 B$ \\
\hline Arachnida & Acari, Oribatida & Hyde & OU 33636.1 & \\
\hline Arachnida & \multicolumn{2}{|c|}{ Acari, Prostigmata (Trombidiformes) Roxburgh } & OU 33160.15 & $2 \mathrm{H}$ \\
\hline Arachnida & Acari, Prostigmata & Roxburgh & OU 33160.22 & $2 \mathrm{G}$ \\
\hline Arachnida & Acari, Prostigmata & Roxburgh & ou 33160.42 & 21 \\
\hline Arachnida & \multicolumn{2}{|c|}{ Acari, Prostigmata (two specimens) Hyde } & OU 33636.2 & $2 \mathrm{C}$ \\
\hline Arachnida & Acari & Roxburgh & OU 33160.16 & $2 \mathrm{~F}$ \\
\hline Arachnida & Acari & Roxburgh & OU 33160.59 & \\
\hline Arachnida & Acari & Roxburgh & ou 33160.66 & \\
\hline Arachnida & Acari & Roxburgh & OU 33160.81 & \\
\hline Arachnida & Acari & Hyde & OU 33636.5 & \\
\hline Arachnida & Acari & Pomahaka & OU 35028.4 & \\
\hline Arachnida & Acari & Pomahaka & OU 35028.5 & \\
\hline Arachnida & Acari & Pomahaka & OU 35028.6 & \\
\hline Arachnida & Araneae & Roxburgh & OU 33160.2 & $2 \mathrm{M}$ \\
\hline Arachnida & Araneae & Roxburgh & OU 33160.4 & $2 \mathrm{~L}$ \\
\hline Arachnida & Araneae & Roxburgh & OU 33160.5 & \\
\hline Arachnida & Araneae & Roxburgh & OU 33160.52 & \\
\hline Arachnida & Araneae & Roxburgh & ou 33160.62 & \\
\hline
\end{tabular}




\begin{tabular}{|c|c|c|c|c|}
\hline Arachnida & Araneae & Roxburgh & OU 33160.63 & \\
\hline Arachnida & Araneae & Roxburgh & OU 33160.66 & \\
\hline Arachnida & Araneae & Roxburgh & OU 33160.77 & \\
\hline Arachnida & Araneae & Hyde & OU 33636.4 & \\
\hline Arachnida & \multicolumn{3}{|c|}{ Pseudoscorpiones, Cheliferidae, Philomaoriinae, Philomaoria Roxburgh OU 33160.29} & $2 \mathrm{~A}$ \\
\hline Arachnida & \multicolumn{2}{|l|}{ Pseudoscorpiones Pomahaka } & OU 35028.1 & \\
\hline Arachnida & \multicolumn{3}{|c|}{ Spider web with prey and stellate plant trichome Roxburgh OU 33160.8} & 20 \\
\hline Arachnida & Spider web & Roxburgh & OU 33160.39 & \\
\hline Arachnida & Spider silk & Roxburgh & OU 33160.41 & \\
\hline Arachnida & \multicolumn{2}{|c|}{ Spider web with insect remains Roxburgh } & OU 33160.45 & $2 \mathrm{~N}$ \\
\hline Arachnida & \multicolumn{2}{|c|}{ Spider web with insect remains Roxburgh } & OU 33160.47 & \\
\hline Entognatha & Collembola & Roxburgh & OU 33160.9 & \\
\hline Entognatha & \multicolumn{3}{|c|}{ Collembola, Entomobryomorpha, Entomobryidae Roxburgh OU 33160.12} & $2 \mathrm{P}$ \\
\hline Entognatha & Collembola & Roxburgh & OU 33160.13 & \\
\hline Entognatha & Collembola & Roxburgh & OU 33160.32 & \\
\hline Entognatha & Collembola & Roxburgh & OU 33160.37 & \\
\hline Entognatha & Collembola & Roxburgh & OU 33160.46 & \\
\hline Insecta & \multicolumn{3}{|c|}{ Coleoptera, Dermestidae, Trogoderma-like larva Roxburgh OU 33160.1} & 31 \\
\hline Insecta & Coleoptera, Chrysomelidae & Roxburgh & OU 33160.51 & $3 \mathrm{H}$ \\
\hline Insecta & Diptera, Cecidomyiidae & Roxburgh & OU 33160.6 & $3 \mathrm{M}$ \\
\hline Insecta & \multicolumn{2}{|c|}{ Diptera, Ceratopogonidae, Austrohelea Pomahaka } & OU 35028.2 & \\
\hline Insecta & \multicolumn{2}{|c|}{ Diptera, Ceratopogonidae, Dasyhelea Roxburgh } & OU 33160.64 & $3 P$ \\
\hline Insecta & \multicolumn{2}{|c|}{ Diptera, Ceratopogonidae, Forcipomyia Roxburgh } & OU 33160.72 & 30 \\
\hline Insecta & \multicolumn{3}{|c|}{ Diptera, Chironomidae, Bryophaenocladius (four specimens) Pomahaka OU 35028.2} & $3 L$ \\
\hline Insecta & \multicolumn{2}{|c|}{ Diptera, Mycetophilidae, Neoaphelomera Roxburgh } & OU 33160.61 & $3 N$ \\
\hline Insecta & Diptera & Roxburgh & OU 33160.44 & \\
\hline Insecta & Diptera & Roxburgh & OU 33160.71 & \\
\hline Insecta & Diptera & Pomahaka & OU 35028.3 & \\
\hline Insecta & \multicolumn{3}{|c|}{ Hemiptera, Fulgoromorpha (planthopper nymph) Pomahaka OU 35020.1} & $3 A$ \\
\hline Insecta & Hemiptera, Sternorrhyncha & Roxburgh & OU 33160.3 & $3 B$ \\
\hline Insecta & Hemiptera, Sternorrhyncha & Roxburgh & OU 33160.43 & $3 C$ \\
\hline
\end{tabular}




\begin{tabular}{|c|c|c|c|c|}
\hline Insecta & Hemiptera, Sternorrhyncha & Roxburgh & OU 33160.76 & \\
\hline Insecta & Hemiptera, Sternorrhyncha & Roxburgh & OU 33160.78 & \\
\hline Insecta & Hymenoptera, Formicidae, Dc & olichoderinae Roxburgh & OU 33160.69 & $3 \mathrm{E}$ \\
\hline Insecta & Hymenoptera, Mymaridae & Roxburgh & OU 33160.17 & $3 G$ \\
\hline Insecta & Hymenoptera, Mymaridae & Roxburgh & OU 33160.89 & \\
\hline Insecta & Hymenoptera, Scelionidae & Roxburgh & OU $33160.183 \mathrm{~F}$ & \\
\hline Insecta & Hymenoptera, Scelionidae & Roxburgh & OU 33160.73 & \\
\hline Insecta & Lepidoptera, wing scales & Roxburgh & OU 33160.35 & $3 \mathrm{~J}$ and $\mathrm{K}$ \\
\hline Insecta & Lepidoptera, wing scales & Roxburgh & OU 33160.82 & \\
\hline Insecta & Psocoptera, Pseudocaeliciida & ae Roxburgh & OU 33160.11 & $3 \mathrm{D}$ \\
\hline Insecta & Large insect legs & Roxburgh & OU 33160.29 & \\
\hline Insecta & Indet. remain & Roxburgh & OU 33160.28 & \\
\hline Insecta & Indet. remain & Roxburgh & OU 33160.33 & \\
\hline Insecta & Indet. remain & Roxburgh & OU 33160.34 & \\
\hline Insecta & Indet. remain & Roxburgh & OU 33160.40 & \\
\hline Insecta & Indet. remain & Roxburgh & OU 33160.53 & \\
\hline Insecta & Indet. remain & Roxburgh & OU 33160.55 & \\
\hline Insecta & Indet. remain & Roxburgh & OU 33160.57 & \\
\hline Insecta & Indet. remain & Roxburgh & OU 33160.60 & \\
\hline Insecta & Indet. remain & Roxburgh & OU 33160.67 & \\
\hline Insecta & Indet. remain & Roxburgh & OU 33160.68 & \\
\hline Insecta & Indet. remain & Roxburgh & OU 33160.70 & \\
\hline Insecta & Indet. remain & Roxburgh & OU 33160.71 & \\
\hline Insecta & Indet. remain & Roxburgh & OU 33160.75 & \\
\hline Insecta & Indet. remain & Roxburgh & OU 33160.108 & \\
\hline Insecta & Indet. remain & Hyde & OU 33636.3 & \\
\hline Insecta & Indet. remain & Pomahaka & OU 35028.7 & \\
\hline Nematoda & & Roxburgh & OU 33160.7 & \\
\hline Nematoda & & Roxburgh & OU 33160.25 & \\
\hline Nematoda & & Roxburgh & OU 33160.30 & \\
\hline Nematoda & & Roxburgh & OU 33160.39 & \\
\hline
\end{tabular}




$\begin{array}{lll}\text { Nematoda } & \text { Roxburgh } & \text { OU } 33160.48 \\ \text { Nematoda } & \text { Roxburgh } & \text { OU } 33160.50 \\ \text { Nematoda } & \text { Roxburgh } & \text { OU } 33160.56 \\ \text { Nematoda } & \text { Roxburgh } & \text { OU } 33160.58 \\ \text { Nematoda } & \text { Roxburgh } & \text { OU } 33160.59 \\ \text { Nematoda } & \text { Roxburgh } & \text { OU } 33160.80\end{array}$

Ascomycota Capnodiales, Metacapnodiaceae, Metacapnodium Roxburgh OU 33160.10

Ascomycota Capnodiales, Metacapnodiaceae, Metacapnodium: Capnophialophora conidial state Roxburgh OU 33160.83 4C

\begin{tabular}{|c|c|c|c|c|}
\hline Ascomycota & Ascospores & Roxburgh & OU 33160.79 & \\
\hline Ascomycota & Conidia in fecal pellets & Roxburgh & OU 33160.56 & $4 \mathrm{~F}$ \\
\hline Ascomycota & Conidia & Hyde & OU 33636.6 & \\
\hline Ascomycota & Conidia & Roxburgh & OU 33160.38 & \\
\hline Ascomycota & Conidia & Roxburgh & OU 33160.54 & \\
\hline Ascomycota & Conidia & Roxburgh & OU 33160.65 & \\
\hline Ascomycota & Conidia & Roxburgh & OU 33160.92 & \\
\hline Ascomycota & Conidia & Roxburgh & OU 33160.93 & \\
\hline Ascomycota & Conidia & Roxburgh & OU 33160.94 & \\
\hline Ascomycota & Conidia & Roxburgh & OU 33160.97 & \\
\hline Ascomycota & Conidia & Roxburgh & OU 33160.102 & \\
\hline Ascomycota & \multicolumn{3}{|c|}{ Dematiaceous hyphomycete with branched conidial chains Roxburgh OU 33160.23} & $4 \mathrm{D}$ \\
\hline Ascomycota & \multicolumn{3}{|c|}{ Dematiaceous hyphomycete with branched conidial chains Roxburgh OU 33160.31} & $4 \mathrm{E}$ \\
\hline Ascomycota & \multicolumn{3}{|c|}{ Dematiaceous hyphomycete with branched conidial chains Roxburgh OU 33160.71} & \\
\hline Ascomycota & \multicolumn{3}{|c|}{ Dematiaceous hyphomycete with branched conidial chains Roxburgh OU 33160.84} & \\
\hline Ascomycota & \multicolumn{3}{|c|}{ Dematiaceous hyphomycete with branched conidial chains Roxburgh OU 33160.85} & \\
\hline Ascomycota & \multicolumn{3}{|c|}{ Dematiaceous hyphomycete with branched conidial chains Roxburgh OU 33160.86} & \\
\hline Ascomycota & \multicolumn{3}{|c|}{ Dematiaceous hyphomycete with branched conidial chains Roxburgh OU 33160.88} & \\
\hline Ascomycota & \multicolumn{3}{|c|}{ Dematiaceous hyphomycete with branched conidial chains Roxburgh OU 33160.91} & \\
\hline Ascomycota & \multicolumn{3}{|c|}{ Dematiaceous hyphomycete with branched conidial chains Roxburgh OU 33160.99} & \\
\hline Ascomycota & \multicolumn{3}{|c|}{ Dematiaceous hyphomycete with branched conidial chains Roxburgh OU 33160.100} & \\
\hline Ascomycota & eous hyphom & ith bra & Roxburgh OU 33160.103 & \\
\hline
\end{tabular}


Ascomycota Dematiaceous hyphomycete with branched conidial chains Roxburgh OU 33160.108

Ascomycota Dematiaceous hyphomycete with branched conidial chains Roxburgh OU 33160.116

Ascomycota Dematiaceous hyphomycete Pomahaka OU 33166.48

Ascomycota Dematiaceous hyphomycete Roxburgh $\quad$ OU 33160.101

Ascomycota Dematiaceous hyphomycete Roxburgh $\quad$ OU 33160.104

Ascomycota Dematiaceous hyphomycete Roxburgh OU 33160.110

$\begin{array}{lll}\text { Ascomycota } & \text { Hyphae and conidia } & \text { Roxburgh } \\ \end{array}$

Ascomycota Hyphae and fecal pellets with conidia Roxburgh $\quad$ OU 33160.96

$\begin{array}{lll}\text { Ascomycota Hyphae } & \text { Hyde } & \text { OU } 33636.4\end{array}$

$\begin{array}{lll}\text { Ascomycota Hyphae } & \text { Hyde } & \text { OU } 33636.5\end{array}$

$\begin{array}{llll}\text { Ascomycota } & \text { Hyphae } & \text { Roxburgh } & \text { OU } 33160.74\end{array}$

$\begin{array}{llll}\text { Ascomycota } & \text { Hyphae } & \text { Roxburgh } & \text { OU } 33169.87\end{array}$

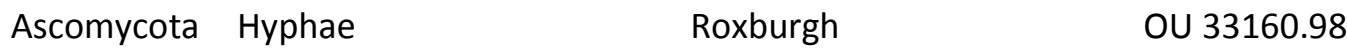

$\begin{array}{lll}\text { Ascomycota } & \text { Hyphae } & \text { Roxburgh } \\ & \text { OU } 33160.113\end{array}$

$\begin{array}{llll}\text { Ascomycota } & \text { Mycelia } & \text { Roxburgh } & \text { OU } 33160.25\end{array}$

$\begin{array}{llll}\text { Ascomycota } & \text { Mycelia } & \text { Roxburgh } & \text { OU } 33160.27\end{array}$

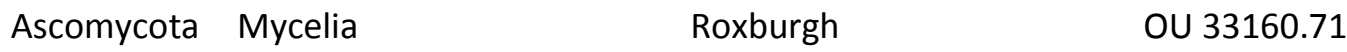

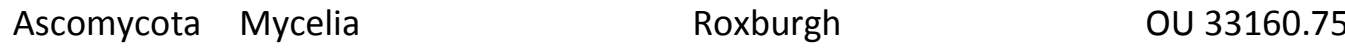

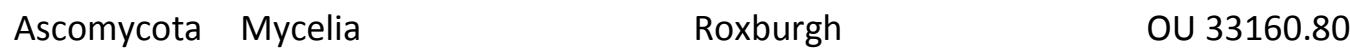

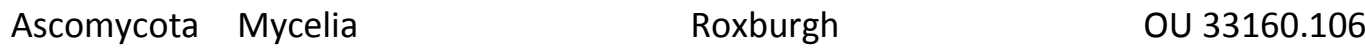

$\begin{array}{llll}\text { Ascomycota } & \text { Mycelia } & \text { Roxburgh } & \text { OU } 33160.107\end{array}$

$\begin{array}{llll}\text { Ascomycota } & \text { Mycelia } & \text { Roxburgh } & \text { OU } 33160.109\end{array}$

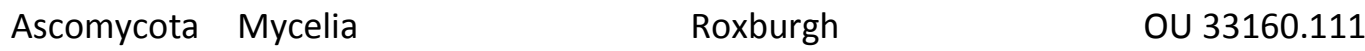

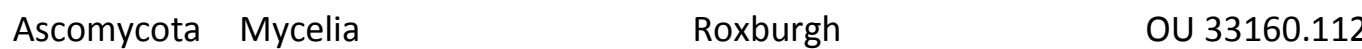

Ascomycota Nematophagous fungi with nematodes Roxburgh $\quad$ OU 33160.48

Tracheophyta Composed stellate plant trichome Roxburgh $\quad$ OU 33160.8

$\begin{array}{lll}\text { Tracheophyta Indet.; trichomes } & \text { Roxburgh } & \text { OU } 33160.26\end{array}$

$\begin{array}{lll}\text { Tracheophyta Indet.; scale } & \text { Roxburgh } & \text { OU } 33160.24\end{array}$

Tracheophyta Indet.; tissue remains with dematiaceous hyphomycetes Pomahaka OU 33166.48 


\section{FIGURES}

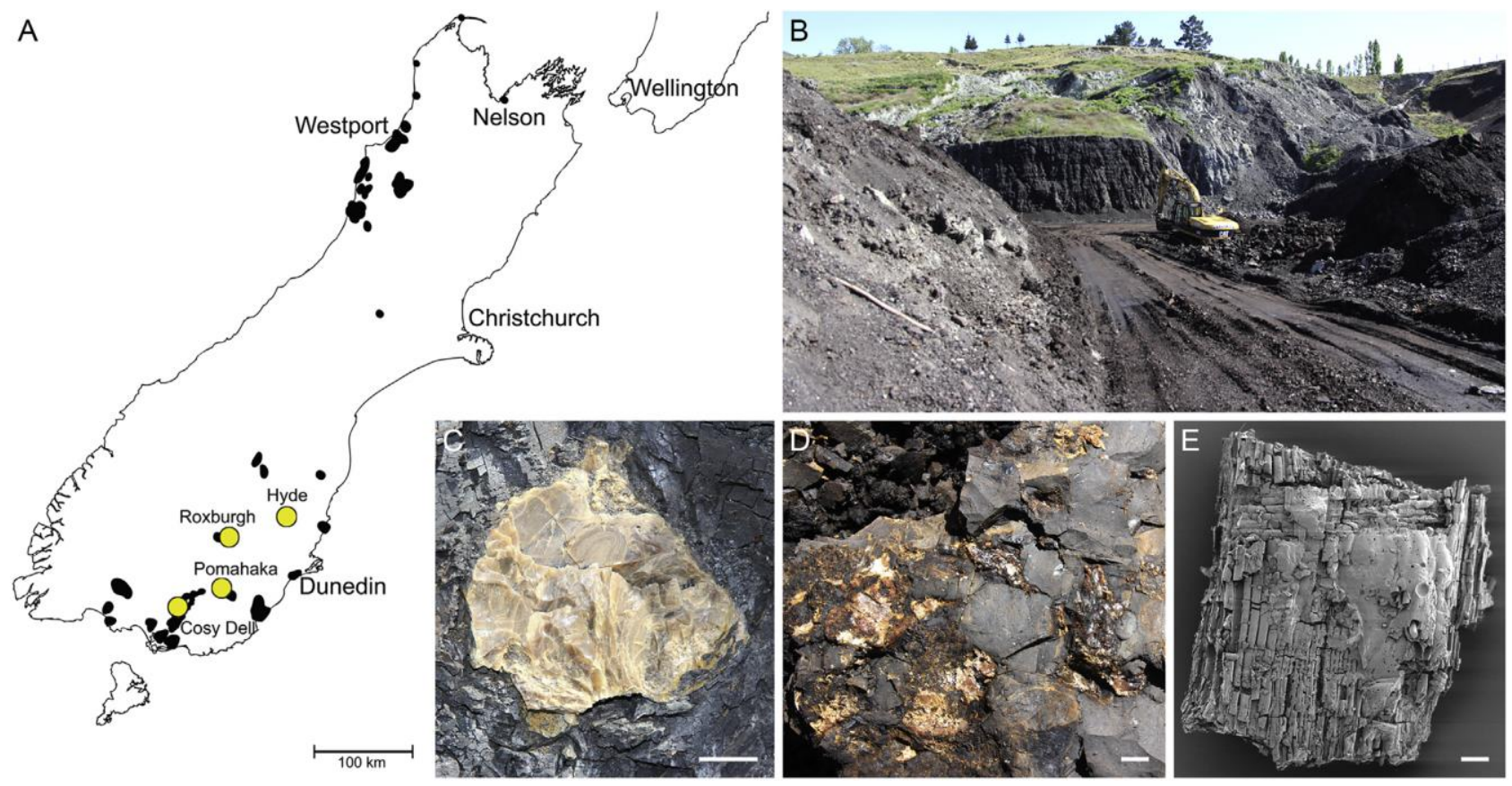

Fig. 1. Amber from New Zealand. (A) Distribution of amber-bearing lignites on South Island, New Zealand (black). Amber with biological inclusions was found in the late Oligocene of Pomahaka and in the early Miocene of Cosy Dell, Hyde and Roxburgh (localities indicated with yellow dots). (B) Harliwich's Pit, East Roxburgh Coal Field, Central Otago. ( $C$ and $D$ ) In situ amber pieces embedded in lignite from Roxburgh. (E) Scanning electron micrograph of araucarian wood extracted from amber. (Scale bars; C, D, $2 \mathrm{~cm} ; \mathrm{E}, 100$ $\mu \mathrm{m}$. 

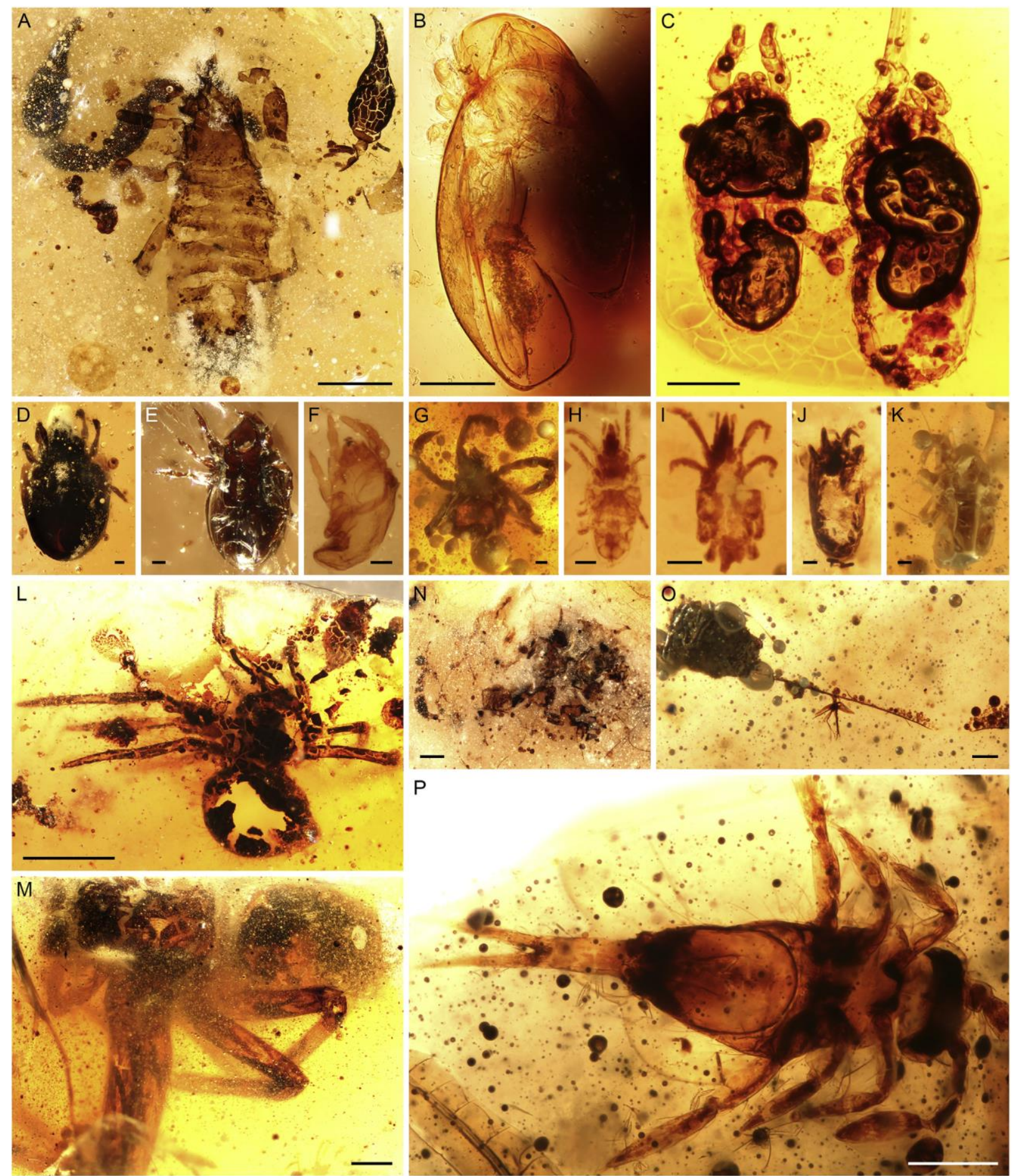

Fig. 2. Arachnids and springtails from early Miocene amber of New Zealand. (A) Pseudoscorpion of the extant genus Philomaoria (OU 33160.29). (B) Oribatid mite of the family Oribotritiidae (Euphthiracaroidea, OU 33161.1). (C) Two prostigmatid mites (OU 33636.2). (D and E) Oribatid mites of the family Scheloribatidae (OU 33160.19 and OU 33160.21). (F) Undetermined Acariformes representative (OU 33160.16). (G, H, and I) Prostigmatid mites (OU 33160.22, OU 33160.15 and OU 33160.42). (J) Astigmatid mite (OU 33160.14). (K) Mesostigmatid mite of the Gamasina cohort (OU 33160.20). (L and M) Juvenile spiders (OU 33160.4 and OU 33160.2). (N) Spider web filaments with trapped insect remains (OU 33160.45). (O) Prey remains and stellate plant hair on spider web filament (OU 33160.8). (P) Collembola of the family Entomobryidae (OU 33160.12). (Scale bars: A and L-N, $500 \mu \mathrm{m} ; \mathrm{B}, \mathrm{C}, \mathrm{O}$ and P, $100 \mu \mathrm{m}$; D-K, 20 $\mu \mathrm{m}$. 

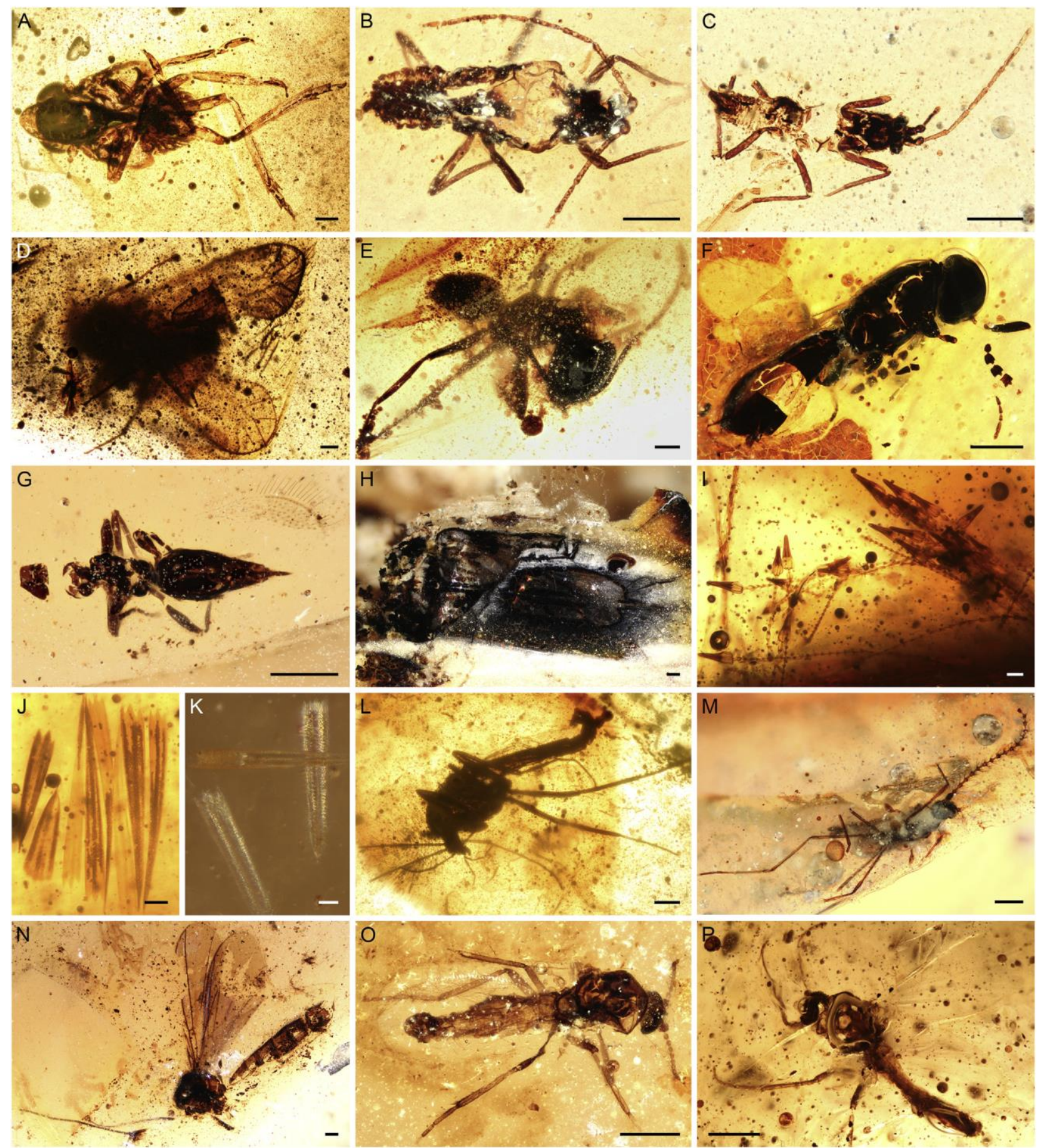

Fig. 3. Pterygote insects from late Oligocene $(A, L)$ and early Miocene (all other images) amber of New Zealand. (A-C) Hemiptera represented by a planthopper (Fulgoromorpha, A, OU 35020.1) and scale insects (B and C, OU 33160.3 and OU 33160.43). (D) Booklouse of the family Pseudocaeliciidae (OU 33160.11). (EG) Hymenoptera represented by an ant of the subfamily Dolichoderinae (E, OU 33160.69), parasitic wasps of the family Scelionidae (F, OU 33160.18) and a Chalcidoidea, possibly Mymaridae (G, OU 33160.17). (H, I) Coleoptera. Dorsal view of possible Chrysomelidae (H, OU33160.51) and hairs at the surface of a larva of the family Dermestidae (I, OU 33160.1). (J, K) Lepidopterawing scales (OU 33160.35). (L-P) Diptera. Chironomidae of the genus Bryophaenocladius (L, OU 35028.2), Cecidomyiidae (M; OU 33160.6), Mycetophilidae of the genus Neoaphelomera ( $\mathrm{N}, \mathrm{OU} 33160.61$ ), Ceratopogonidae of the genera Forcipomyia (O, OU 33160.72) and Dasyhelea (P, OU 33160.64). (Scale bars: A-H and L-P, $200 \mu \mathrm{m}$; I-K, 20 $\mu \mathrm{m}$. 

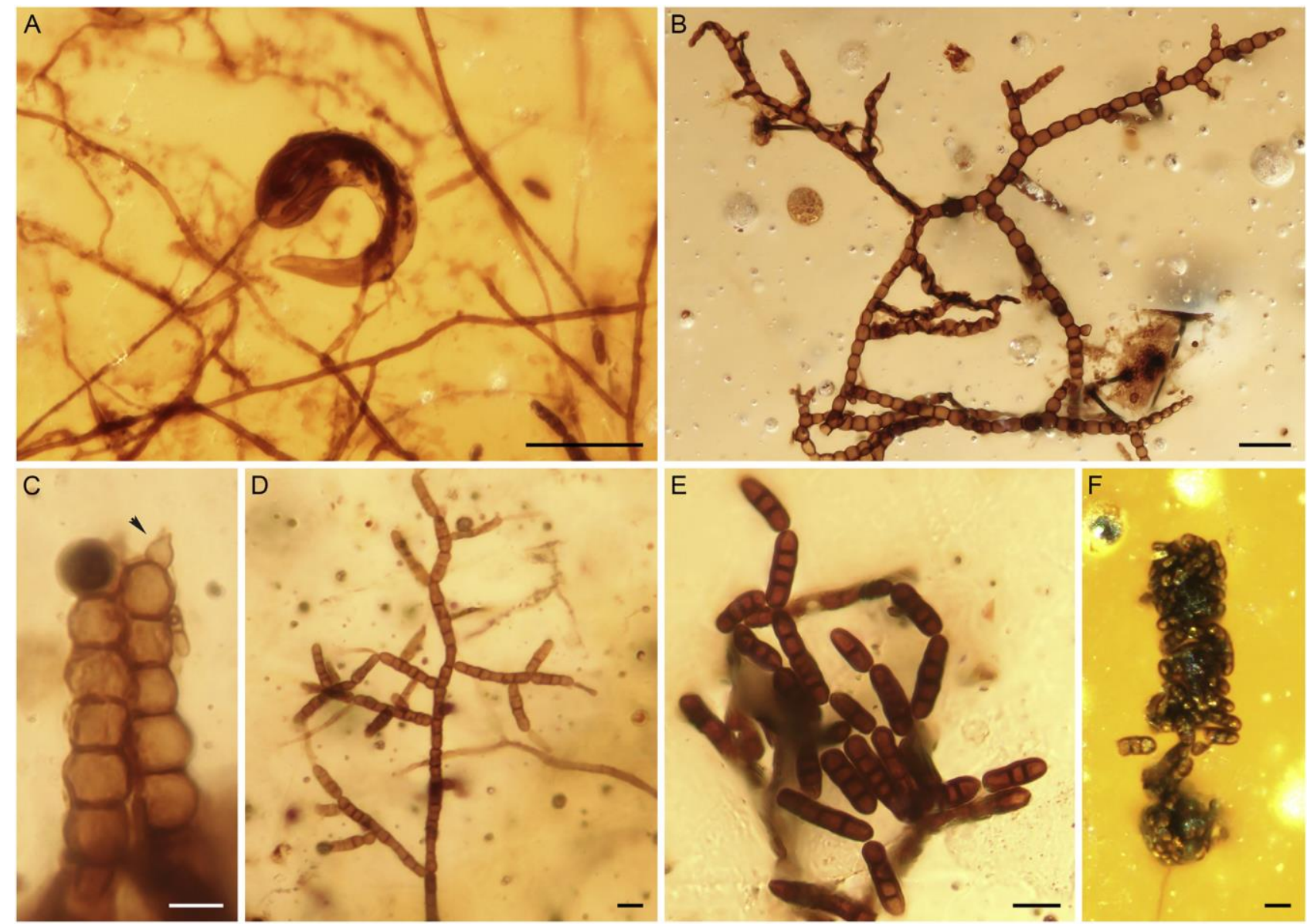

Fig. 4. Fungi and micrometazoans from early Miocene amber of Roxburgh (New Zealand). (A) Mycelium of a nematophagous fungus with a trapped nematode. Hyphae are visible at the surface and inside the nematode (OU 33160.48). (B and C) Sooty mold of the Metacapnodiaceae (Ascomycota, OU 33160.10 and OU 33160.83). The arrowhead in C points to the Capnophialophora conidial state. ( $D$ and E) Dematiaceous hyphomycete with branched conidial chains (OU 33160.23 and OU 33160.31). E shows a cluster of abscised septate conidia. (F) Arthropod fecal pellet composed of remains of conidia of the fungus shown in $D$ and $E$ (OU 33160.56). (Scale bars: A, B, $50 \mu \mathrm{m} ; \mathrm{C}-\mathrm{F}, 10 \mu \mathrm{m}$.) 